\title{
ANALYSIS OF ELASTIC DEFORMATION OF AMORPHOUS POLYETHYLENE IN UNIAXIAL TENSILE TEST BY USING MOLECULAR DYNAMICS SIMULATION
}

\author{
TIEN-THINH LE* \\ Université Paris-Est, Laboratoire Modélisation et Simulation Multi Echelle, MSME UMR 8208 CNRS, \\ 5 bd Descartes, 77454 Marne-la-Vallée, France \\ *Corresponding author: tien-thinh.le@univ-paris-est.fr
}

\begin{abstract}
In this paper, the linear elastic response to uniaxial tension of amorphous polyethylene was investigated by using Molecular Dynamics (MD) simulation. The polymeric system was initiated using a Monte Carlo-based technique and then equilibrated by a relaxation sequence at temperature of $100 \mathrm{~K}$ under a NPT control. Uniaxial tension test was carried out by modifying the corresponding component of the pressure tensor, with a loading rate of $0.5 \mathrm{bar} / \mathrm{ps}$. The results showed that at $100 \mathrm{~K}$ (which is smaller than the glass transition temperature), the amorphous polymeric material exhibited a linear elastic response to uniaxial tension. The obtained Young's modulus and Poisson's ratio were also compared with values reported in the literature. Finally, parametric studies were performed on the stress-strain curve as a function of loading axis, number of chains and number of monomer units, respectively.
\end{abstract}

Key words: Uniaxial tension, Molecular Dynamics simulation, Amorphous polyethylene, Elasticity

\section{INTRODUCTION}

Polymers, especially polyethylene, are crucial in materials science as they are widely applied in various industrial materials (Fang et al. 2018). From mechanical modeling point of view, polyethylene materials are in nature highly complex, as their mechanical behavior are affected by various parameters, especially from molecular scales (Hossain et al. 2010). To understand such a complex behavior, Molecular Dynamics (MD), have been widely used to simulate polymer systems at various length and time scales (Rapaport 2004). Indeed, Capaldi et al. (2004) have found that deformation mechanism of polyethylene highly depended on the local flexibility along the polymer chains. Hossain et al. (2010) have employed atomistic simulations to study both local and macroscopic deformation mechanisms of amorphous polyethylene as a function of bond length, bond angle, dihedral distributions as well as chain length and number. In another study, Brown et al. (1991) have investigated numerically elastic deformation, yield and plastic response of polyethylene at various deformation rates. Depa \& Maranas (2007) have used coarse-grained MD simulations to explore the dynamic evolution of polyethylene melts. Lavine et al. (2003) have shown that orientation and crystallization of polyethylene affected the deformation mechanisms of such material.

Although various investigations have been introduced to study the static and/or dynamic mechanical responses of polyethylene, researches on amorphous polyethylene need to be more explored, especially in pointing out the influence in molecular level to the macroscopic response (Fang et al., 2018; Hossain et al., 2010). As MD is an efficient tool to study polymer processes at the molecular scale, the main objective of this study is to determine the linear elastic response to uniaxial tension of amorphous polyethylene by using MD simulations. The coarse graining 
technique was used to simulate polyethylene units, therefore, allow investigating the effect of number of chains and number of units on the stress-strain response. Finally, a comparison with literature was studied and discussed.

\section{MATERIALS AND METHODS}

\subsection{Molecular Dynamics simulation}

Based on Newton's laws, Molecular Dynamics (MD) is able to describe the dynamics of a particulate system at the atomic or molecular scale (Allen et al., 1989). The dynamic evolution of this system as a function of time is characterized by interaction between particles themselves inside and also with the environment outside (Liu et al., 2006; Frenkel \& Smit, 2001). Therefore, using a system of equations of motion based on Newton's law, the positions, velocities, accelerations, forces of the particles can be connected with time. A diagram of the main steps of MD is shown in figure 1, including initialization, calculation of potential energy, calculation of forces, calculation of accelerations, integration of equations of motions, updating positions, velocities, etc. As MD is a well-established method, more details could be found in (Frenkel \& Smit, 2001).

\subsection{Polyethylene model}

In this work, as interested in the isotropic behavior of materials, a linear amorphous polyethylene was selected for numerical investigation. The polymer was made up of $n$ chains, each consisting of $1000 \mathrm{CH} 2$ coarse-graining units. The molar mass of each $\mathrm{CH} 2$ unit is $14.0273 \mathrm{~g} / \mathrm{mol}$. The potentials of the system were composed of four terms including a truncated Lennard-Jones 12-6, denoted by $E_{L J}$, two harmonic potentials denoted by $E_{b}$ and $E_{\theta}$ and a torsional potential denoted by $E_{\phi}$, respectively. The details of these potentials are presented below, together with their parameters indicated in table 1 (Shepherd et al., 2006; Brown et al. 2003):

$$
E=E_{L J}+E_{b}+E_{\theta}+E_{\phi}
$$

where:

$$
\begin{aligned}
& E_{L J}(r)=\left\{\begin{array}{l}
4 \alpha\left[\left(\frac{\beta}{r}\right)^{12}-\left(\frac{\beta}{r}\right)^{6}\right], r \leq r_{c} \\
0, r>r_{c}
\end{array}\right. \\
& E_{b}(r)=0.5 K_{b}\left(r-r_{0}\right)^{2} \\
& E_{\theta}(\theta)=0.5 K_{\theta}\left[\cos (\theta)-\cos \left(\theta_{0}\right)\right]^{2}
\end{aligned}
$$

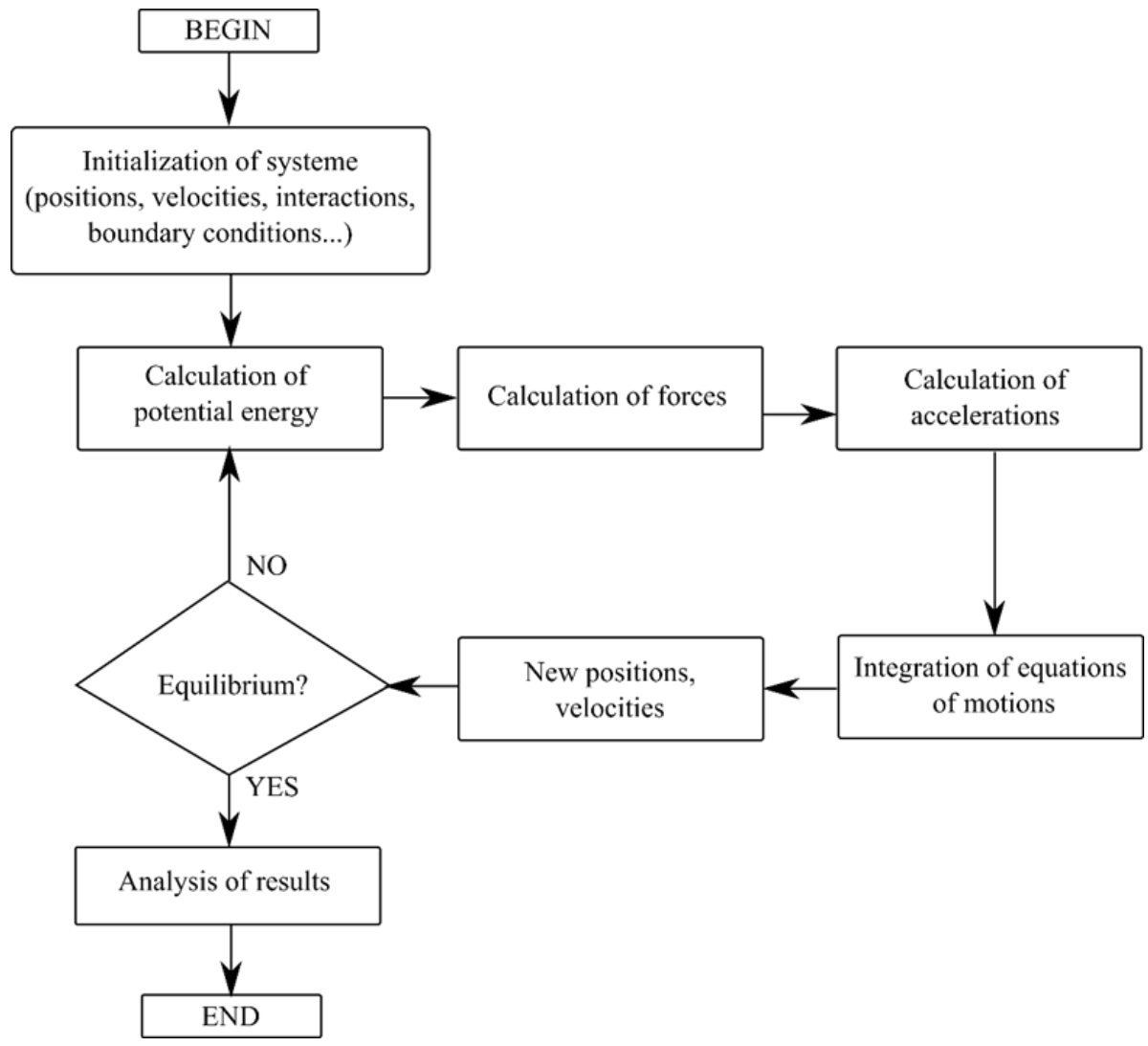

Fig. 1. Main steps of MD simulation. 


$$
E_{\phi}(\phi)=\sum_{i=1}^{5} A_{i}[\cos (\phi)]^{i-1}
$$

Table 1. Data used for material description in numerical modeling.

\begin{tabular}{|c|c|}
\hline Potential & Value of parameter \\
\hline$E_{L J}$ & $\alpha=0.1133 \mathrm{kcal} / \mathrm{mol} ; \beta=0.43 \mathrm{~nm}$ \\
\hline$E_{b}$ & $K_{b}=70000 \mathrm{kcal} /(\mathrm{mol} . \mathrm{nm} 2) ; r_{0}=0.15 \mathrm{~nm}$ \\
\hline$E_{\theta}$ & $K_{\theta}=124.28 \mathrm{kcal} / \mathrm{mol} ; \theta_{0}=112.81^{\circ}$ \\
\hline & $A_{1}=2.1109 \mathrm{kcal} / \mathrm{mol} ; A_{2}=4.3229$ \\
$E_{\phi}$ & $\mathrm{kcal} / \mathrm{mol} ; A_{3}=1.1665 \mathrm{kcal} / \mathrm{mol} ; A_{4}=-$ \\
& $7.6004 \mathrm{kcal} / \mathrm{mol} ; A_{5}=0$ \\
\hline
\end{tabular}

Initial configuration of polymers was generated in this study using a Monte Carlo-based technique, called "Self Avoiding Random Walk" (Hossain et al. 2010). MD simulations were then performed to obtain a relaxation state of the polymer system satisfying the force field presented above at $100 \mathrm{~K}$ (under Nosé-Hoover isothermal-isobaric (NPT) control (Rapaport, 2004)). It should be noticed that $100 \mathrm{~K}$ was chosen in this study as equilibrium temperature to obtain typical elastic behavior of polymeric materials (because this temperature is much lower than the glass transition one of polyethylene which is about $250 \mathrm{~K}$ (Hossain et al., 2010)). In this work, a time step of $2 \mathrm{fs}$ was used as recommended by Brown et al. (2008) for coarse-grained simulations. MD simulations were performed using LAMMPS code (Nguyen \& Plimpton, 2019).
To realize a uniaxial tensile test for the polymeric materials, non-equilibrium MD simulations were performed by linearly modifying the corresponding component of the pressure tensor (with a loading rate equal of $0.5 \mathrm{bar} / \mathrm{ps}$, which is small enough to limit viscosity effects while testing). For instance, a uniaxial tensile test along the $\mathrm{x} 1$ axis is carried out by changing linearly the component P11 of the pressure tensor while keeping all others constant (Marcadon et al., 2013).

\section{RESULTS AND DISCUSSION}

\subsection{Relaxation of polymer chains}

An initial configuration of 80 chains was generated by using "Self Avoiding Random Walk" algorithm. This initial structure was then inserted into the LAMMPS code for simulating the relaxation process. Figure 1 shows a relaxation sequence of the polymer system (in a cut view mode of the 3D simulation box). Figure $2 \mathrm{a}$ presents a relaxed polymer chain while figure $2 b$ shows the simulation box of 80 chains equilibrated at the desired temperature. It should be noticed that such orthogonal simulation box has a length of about $13.2 \mathrm{~nm}$.

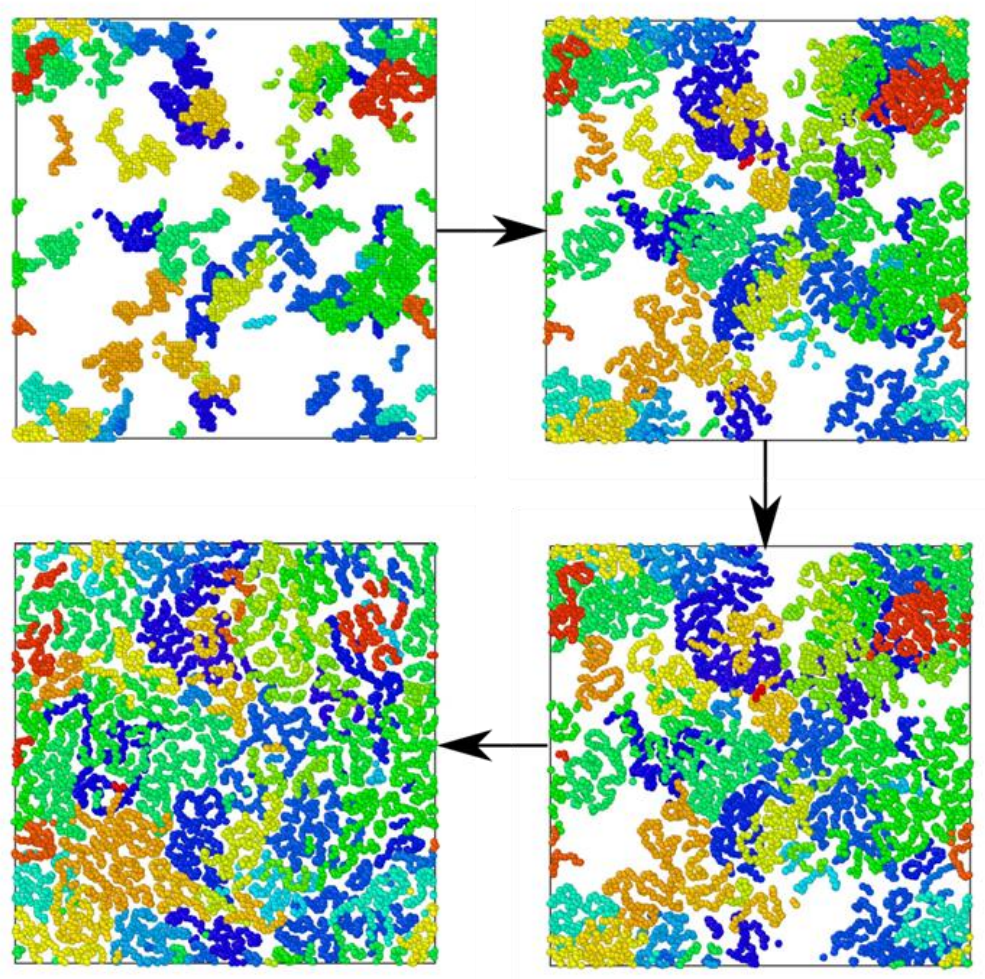

Fig. 2. Relaxation sequence of polymeric system from initial configuration to amorphous structure. 


\subsection{Uniaxial tension.}

The amorphous polyethylene was then deformed under a uniaxial tensile test. Figure 4 a shows a deformed state of the simulation box at $25 \%$ of strain (for illustration purpose), while the corresponding initial configuration (i.e. 0\% of strain) is shown in figure $3 \mathrm{~b}$. The stress-strain curves up to $1 \%$ of strain are presented in figure $4 \mathrm{~b}$, while realized tension test along $x_{1}, x_{2}$, and $x_{3}$ axes, respectively. The result shows that at $100 \mathrm{~K}$ (which is lower than the glass transition temperature), the polymeric material presents a linear elastic behavior up to $1 \%$ of strain in a uniaxial tensile test. Besides, despite the fluctuations observed in figure $4 \mathrm{~b}$ for three stress-strain responses, it could be concluded that the amorphous system exhibits an isotropic behavior as expected.

a)
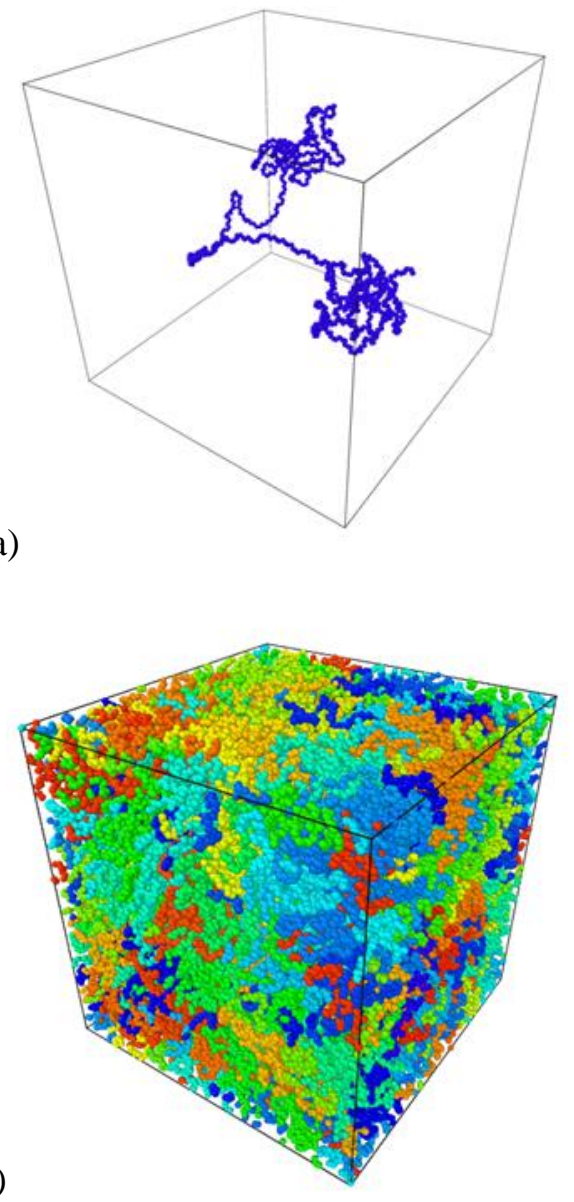

Fig. 3. Relaxed configuration for (a) a polymer chain and (b) the simulation box.

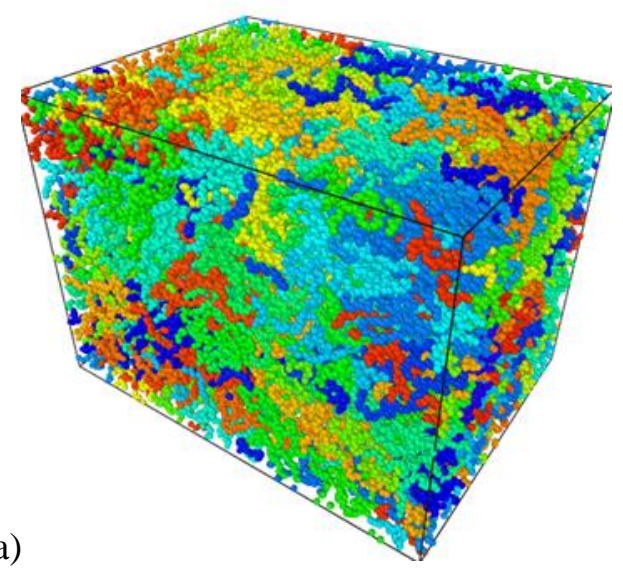

b)

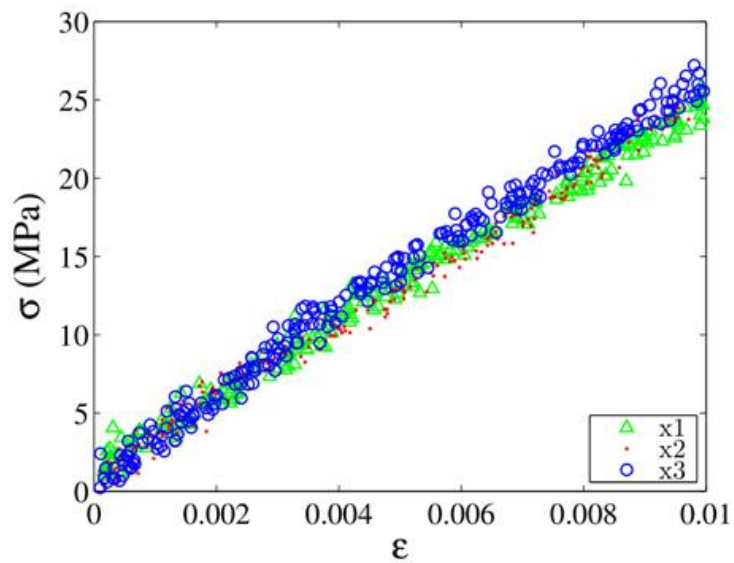

Fig. 4. Results of uniaxial tensile test: (a) deformed state at $25 \%$ of strain (for illustration purpose) and (b) stress-strain curves up to $1 \%$ of strain.

The parametric studies were performed as a function of number of polymer chains (figure 5a) and number of monomers (figure $5 \mathrm{~b}$ ). As observed in figure $5 \mathrm{a}$, a simulation box containing 10 chains produced higher fluctuations in terms of stress-strain response than one containing 80 chains (the 10 chains system had a length of $6.6 \mathrm{~nm}$, while the 80 chains system had a length of $13.2 \mathrm{~nm}$ ). Such fluctuations were related directly to the number of monomer units in the simulation box (i.e. 10000 and 80000 , respectively). The stress-strain responses shown in figure $5 \mathrm{~b}$ confirmed the relevance of this remark, as keeping the same number of monomer units in the simulation box (i.e. 80000). Nonetheless, as shown in figure 5a, both 10 and 80 chains systems exhibited similar mechanical behavior in a uniaxial tensile test. 


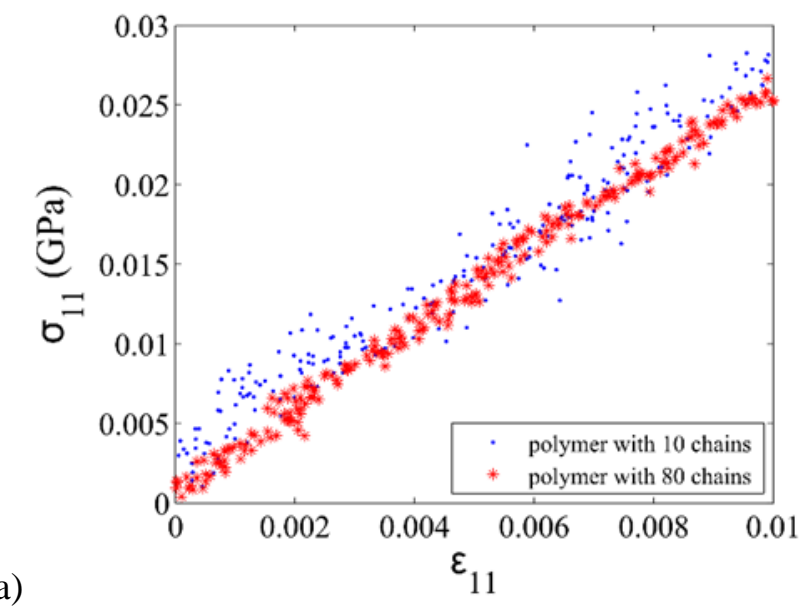

a)

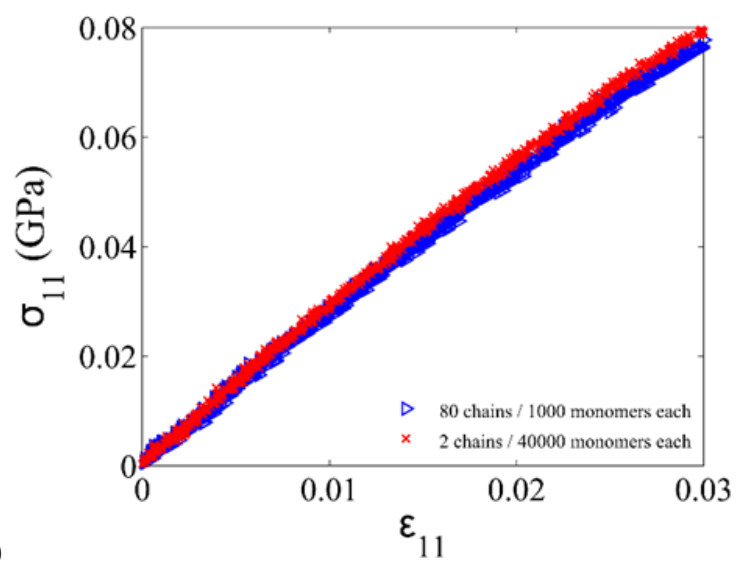

Fig. 5. Evaluation of the influence of (a) number of polymer chains and (b) number of monomer units on the stress-strain response.

From the slope of the stress-strain response from 0 to $1 \%$ of strain, Young's modulus of the material was computed and shown in table 2, together with a comparison with other works in the literature. It should be noticed that based on the deformation of the simulation box during tension test, Poisson's ratio was also calculated and reported in table 2. All results were reported for polyethylene at $100 \mathrm{~K}$, however, at different deformation rates and boundary conditions. As mentioned in (Brown \& Clarke, 1991), (Marcadon et al., 2013), and this work, the tensile test was performed by applying pressure condition at the boundary. However, the material in (Hossain et al., 2010) and (Capaldi et al., 2004) was deformed under a constant strain rate applying to the simulation box. In addition, there are also a difference in control algorithms and generations of initial configuration. Consequently, there is a variation in the values of Young's modulus reported for amorphous polyethylene at $100 \mathrm{~K}$. Regarding Poisson's ratio, the value reported in this work is very close to other works, except (Capaldi et al., 2004) (i.e. 0.42 and 0.35 , respectively). Nonetheless, the mechanical response of amorphous polyethylene obtained in this work is qualitatively similar to that achieved in the literature, especially is consistent with the elastic moduli of glassy polymers reported experimentally (Maillard et al., 2012; Xia \& Keten, 2015).

Table 2. Data used for material description in numerical modeling.

\begin{tabular}{|c|c|c|c|c|}
\hline Ref. & $\begin{array}{c}\text { Young's } \\
\text { modulus } \\
\text { GPa }\end{array}$ & $\begin{array}{c}\text { Pois- } \\
\text { son's } \\
\text { ratio }\end{array}$ & $\begin{array}{c}\text { Tempera- } \\
\text { ture, } \mathrm{K}\end{array}$ & Rate \\
\hline $\begin{array}{c}\text { (Brown \& } \\
\text { Clarke, } \\
\text { 1991) }\end{array}$ & 2.4 & 0.41 & 100 & $\begin{array}{c}\text { Loading } \\
\text { rate of 5 } \\
\text { bar/ps }\end{array}$ \\
\hline $\begin{array}{c}\text { (Brown \& } \\
\text { Clarke, } \\
\text { 1991)) }\end{array}$ & 2.3 & 0.41 & 100 & $\begin{array}{c}\text { Loading } \\
\text { rate of 1 } \\
\text { bar/ps }\end{array}$ \\
\hline $\begin{array}{c}\text { (Hossain } \\
\text { et al.,. } \\
\text { 2010) }\end{array}$ & 1.6 & - & 100 & $\begin{array}{c}\text { Strain } \\
\text { rate of } \\
10^{-9} \mathrm{~s}^{-1}\end{array}$ \\
\hline $\begin{array}{c}\text { (Marca- } \\
\text { don et al., } \\
\text { 2013) }\end{array}$ & 1.84 & 0.433 & 100 & $\begin{array}{c}\text { Loading } \\
\text { rate of 1 } \\
\text { bar/ps }\end{array}$ \\
\hline
\end{tabular}

Results of this work indicate that the elastic deformation of amorphous polyethylene can be simulated numerically (by MD in this case) in a qualitative agreement with the literature. In addition, it is observed that at a much lower temperature $(100 \mathrm{~K})$ than the glass transition one $(250 \mathrm{~K})$, the polymeric material exihibits a linear elastic behavior in a uniaxial tensile test. Moreover, the isotropic behavior of the amorphous system was also verified. Such a result could be served as inputs for modeling the mechanical behavior of nano-reinforced polymers by using micromechanical schemes. On the other hand, as proved in this study, MD can also be employed for simulating the mechanical behavior of the polymeric system with nanofiller reinforcement. Such a simulation could be useful for coupling with micromechanical frameworks. Certainly, various aspects should be investigated in further researches. The deformation mechanisms of the polymeric materials should be explored from the molecular scales (i.e. potentials, energy evolution) (Yashiro et al., 2003). The plastic deformation of such a material should be further considered, especially for revealing the yield, stress softening and strain hardening (Hossain et al., 2010; Tschopp et al., 2011). Finally, a complete apparent elasticity tensor should be derived for the polymeric material as well as one with nanofiller reinforcement (Vu-Bac et al., 2016). 


\section{CONCLUSIONS}

In this work, numerical MD simulations were performed for investigating elastic response to uniaxial tension of amorphous polyethylene. Coarsegraining model was employed for modeling the polyethylene units, together with various potentials such as Lennard-Jones, bond, angle and dihedral, respectively. MD simulations allowed relaxing the polymer system of $n$ chains from initial configuration, and performing uniaxial tensile test with a loading rate of $0.5 \mathrm{bar} / \mathrm{ps}$. The stress-strain response to uniaxial tension was analyzed as a function of loading axis, number of chains and number of monomer units. The elastic moduli of amorphous polyethylene obtained in this work were qualitatively in accordance with that reported in the literature, especially for glassy polymers.

\section{ACKNOWLEDGMENTS}

The author would like to thank Prof. J. Guilleminot (Duke University, Durham, USA), for his helpful advice and comments on this paper.

This research received no external funding.

The authors declare no conflict of interest.

The raw/processed data required to reproduce these findings will be made available on request.

\section{REFERENCES}

Allen, M.P., Tildesley, D.J., 1989. Computer Simulation of Liquids, Clarendon Press.

Brown, D., Marcadon, V., Mélé, P., Albérola, N.D., 2008. Effect of filler particle size on the properties of model nanocomposites, Macromolecules, 41(4), 1499-1511. https:// doi.org/10.1021/ma701940j.

Brown, D., Mélé, P., Marceau, S., Albérola, N.D., 2003, A molecular dynamics study of a model nanoparticle embedded in a polymer matrix, Macromolecules, 36(4), 13951406, https://doi.org/10.1021/ma020951s.

Brown, D, Clarke, J.H.R., 1991, Molecular dynamics simulation of an amorphous polymer under tension. 1. Phenomenology, Macromolecules, 24(8), 2075-2078, https://doi.org/ 10.1021/ma00008a056.

Capaldi, FM., Boyce, M.C., Rutledge, G.C., 2004, Molecular response of a glassy polymer to active deformation, Polymer, Modeling of Chain Conformations and Spatial Configurations, 45(4), 1391-99, https://doi.org/10.1016/ j.polymer.2003.07.011.

Depa, P.K., Maranas, J.K., 2007, Dynamic evolution in coarsegrained molecular dynamics simulations of polyethylene melts, The Journal of Chemical Physics, 126(5), 054903. https://doi.org/10.1063/1.2433724.

Fang, Q, Tian, Y., Hong W., Jia, L., 2018, revealing the deformation mechanism of amorphous polyethylene subjected to cycle loading via molecular dynamics simulations, $R S C$ Advances, 8(56), 32377-32386, https://doi.org/10.1039/ C8RA05868G.
Frenkel, D., Smit, B., 2001, Understanding molecular simulation: from algorithms to applications. 2nd ed., Academic Press, San Diego.

Hossain, D., Tschopp, M.A., Ward, D.K., Bouvard, J.L., Wang, P, Horstemeyer, M.F, 2010, Molecular dynamics simulations of deformation mechanisms of amorphous polyethylene, Polymer, 51(25): 6071-83, https://doi.org/10.1016/ j.polymer.2010.10.009.

Lavine, M.S., Waheed, N., Rutledge, G.C., 2003, Molecular dynamics simulation of orientation and crystallization of polyethylene during uniaxial extension, Polymer, 44(5): 1771-1779, https://doi.org/10.1016/ S0032-3861(03)00017 $-\mathrm{X}$.

Liu, W.K., KarpovE.G., Park, H.S., 2006, Nano mechanics and materials: theory, multiscale methods and applications, $1 \mathrm{st}$ ed., Wiley, Chichester, Hoboken.

Maillard, D., Kumar, S.K., Fragneaud, B., Kysar, J.W., Rungta, A., Benicewicz, B.C., Deng, H., Brinson, L.F., Douglas, 2012, Mechanical properties of thin glassy polymer films filled with spherical polymer-grafted nanoparticles, Nano Letters, 12(8), 3909-3914, https://doi.org/10.1021/ $\mathrm{nl} 301792 \mathrm{~g}$.

Marcadon, V., Brown, D., Hervé, E., Mélé, P., Albérola, N.D., Zaoui, A., 2013, Confrontation between Molecular Dynamics and micromechanical approaches to investigate particle size effects on the mechanical behaviour of polymer nanocomposites, Computational Materials Science, $79,495-505$.

Nguyen, T.D., Plimpton, S.J., 2019, Aspherical particle models for molecular dynamics simulation, Computer Physics Communications, 243, 12-24, https://doi.org/10.1016/ j.cpc. 2019.05.010.

Rapaport, D.C., 2004, The art of molecular dynamics simulation, 2nd ed., Cambridge University Press, Cambridge, New York.

Shepherd, J.E., McDowell, D.L., Jacob, K.I., 2006, Modeling morphology evolution and mechanical behavior during thermo-mechanical processing of semi-crystalline polymers, Journal of the Mechanics and Physics of Solids, 54, 467-489, https://doi.org/10.1016/j.jmps.2005.10.003.

Tschopp, M.A., Bouvard, J.L., Ward, D.K., Horstemeyer, M.F., 2011, atomic scale deformation mechanisms of amorphous polyethylene under tensile loading, 2011, Supplemental Proceedings, Vol 2: Materials Fabrication, Properties, Characterization and Modeling, John Wiley \& Sons, Ltd., 789-794, https://doi.org/10.1002/9781118062142.ch95.

Vu-Bac, N., Areias, P.M.A., Rabczuk, T., 2016, A multiscale multisurface constitutive model for the thermo-plastic behavior of polyethylene, Polymer, 2016, 105, 327-338. https://doi.org/10.1016/j.polymer.2016.10.039.

Xia, W., Keten. 2015, Size-dependent mechanical behavior of free-standing glassy polymer thin films, Journal of Materials Research, 30(1), 36-45, https://doi.org/10.1557/ jmr.2014.289.

Yashiro, K., Ito, T., Tomita, Y., 2003, Molecular dynamics simulation of deformation behavior in amorphous polymer: nucleation of chain entanglements and network structure under uniaxial tension, International Journal of Mechanical Sciences, 45(11), 1863-1876, https://doi.org/10.1016/ j.ijmecsci.2003.11.001. 
SPRĘŻYSTE ODKSZTALCENIE

AMORFICZNEGO POLIETYLENU W

OSIOWOSYMETRYCZNEJ PRÓBIE

ROZCIAGANIA Z ZASTOSOWANIEM

SYMULACJI METODĄ DYNAMIKI

MOLEKULARNEJ

\section{Streszczenie}

W pracy przeprowadzono badania metodą dynamiki molekularnej sprężystej odpowiedzi amorficznego polietylenu w osiowosymetrycznej próbie rozciągania. System polimetryczny został zainicjowany metodą Monte Carlo a następnie zrównoważony poprzez relaksację w temperaturze $100 \mathrm{~K}$ ze sterowaniem NPT. Próby rozciągania przeprowadzono poprzez zmodyfikowanie odpowiedniej składowej tensora naprężeń, przyjmując prędkość obciążania $0.5 \mathrm{bar} / \mathrm{ps}$. Wyniki wykazały, że w temperaturze 100 $\mathrm{K}$ (która jest niższa od temperatury zeszklenia), amorficzny polimer wykazuje liniową sprężystość w próbie rozciągania. Wyznaczone wartości modułu Younga i współczynnika Poissona zostały porównane $\mathrm{z}$ danymi literaturowymi. Wreszcie przeprowadzono parametryczną ocenę krzywych naprężenieodkształcenie w zależności od kierunku obciążenia, liczby łańcuchów oraz liczby jednostek monomeru.

Received: June 10, 2020 Received in a revised form: June 15, 2020. Accepted: July 20, 2020 